\title{
PENDUGAAN KOMPONEN GENETIK, DAYA GABUNG, DAN SEGREGASI BIJI PADA JAGUNG MANIS KUNING KISUT
}

\author{
Tanty Yunita Saputri, Saiful Hikam \& Paul B. Tomotiwu \\ Jurusan Agroteknologi, Fakultas Pertanian Universitas Lampung \\ Jl. Prof. Soemantri Brojonegoro, No. 1, Bandar Lampung 35145 \\ E-mail: ade.bawel@yahoo.co.id
}

\begin{abstract}
ABSTRAK
Evaluasi keturunan biasanya dikaitkan dengan kemampuan tetua dalam suatu persilangan yang disebut daya gabung. Daya gabung adalah kemampuan genotipe untuk mewariskan karakter yang diinginkan (sifat interest) kepada keturunannya. Peningkatan kualitas sangat penting dalam pemuliaan jagung manis. Perakitan jagung manis kuning kisut merupakan hasil dari persilangan tetua kuning bulat dan kuning kisut. Penelitian ini bertujuan untuk; (1) mengevaluasi daya gabung tetua inbred kepada zuriat kuning kisut polinasi terbuka; (2) mengetahui adanya ragam genetik dan heritabilitas untuk sifat-sifat interest yang dievaluasi; dan (3) mengevaluasi perbandingan biji jagung manis kuning kisut 12:4. Penelitian ini dilakukan dalam Rancangan Acak Kelompok Lengkap (RAKL) dengan tiga ulangan. Data dianalisis ragam untuk mendapatkan kuadrat nilai tengah dan kuadrat nilai tengah harapan yang akan digunakan untuk menduga ragam genetik dan heritabilitas. Ragam genetik $\left(\hat{\sigma}^{2} \mathrm{~g}\right)$ dan heritabilitas broad-sense $\left(\mathrm{h}_{\mathrm{BS}}^{2}\right)$ dihitung menggunakan model matematika berdasarkan Hallauer dan Miranda. Analisis daya gabung dilakukan dengan analisis boxplot. Segregasi biji jagung manis true type dihitung dengan cara membandingkan jumlah biji kisut dengan jumlah biji seluruhnya dalam satu tongkol. Berdasarkan hasil penelitian, perbedaan antarkultivar nyata untuk karakter jumlah daun, jumlah malai, dan diameter tongkol. Sedangkan Karakter tinggi tanaman, posisi tongkol, jumlah daun, panjang tongkol, jumlah baris biji per tongkol, dan kadar sukrosa tidak berbeda. Nilai ragam genetik dan heritabilitas lebih besar dari nol (> 1 GB) untuk karakter jumlah daun, jumlah malai, diameter tongkol. Nilai ragam genetik tidak berbeda dari nol (<1 GB) untuk karakter tinggi tanaman, posisi tongkol, jumlah baris biji, panjang tongkol, dan kadar sukrosa. Daya gabung umum terbukti pada karakter tinggi tanaman, posisi tongkol, jumlah daun, jumlah malai, panjang tongkol, dan jumlah baris per biji. Daya gabung khusus terbukti pada karakter diameter tongkol, dan kadar sukrosa. Dari 15 tongkol jagung manis yang diamati tidak semuanya merupakan jagung manis dengan fenotipe biji kuning kisut. Beberapa tongkol mengandung biji putih pada tongkolnya yaitu pada ulangan dua sampel satu, dua, empat dan pada ulangan tiga sampel dua, empat, lima.
\end{abstract}

Kata Kunci : daya gabung, jagung, sifat interest, tetua inbred

\section{PENDAHULUAN}

Jagung manis (Zea mays saccharata [Sturt.] Bailey) merupakan salah satu komoditas hortikultura yang disukai masyarakat. Jagung manis disukai karena rasanya yang enak, mengandung karbohidrat, protein, dan vitamin tinggi, serta kandungan lemaknya rendah. Selain itu juga nilai ekonomi jagung manis tinggi. Secara komersial harga jagung manis ditentukan oleh kualitas tongkol muda. Tongkol jagung manis dapat dipanen sebagai jagung semi (78-80 hst) (Hikam, 2003).

Secara alami jagung adalah spesies kros $(99,9 \%$ kros). Walaupun monoesius, bunga jantan jagung matang lebih dahulu dibandingkan bunga betinanya (protandri) (Fehr, 1987). Tabur polen antesis terjadi 4-10 hari sebelum munculnya rambut tongkol (silk). Adanya selang waktu ini memungkinkan polen dari satu tanaman untuk memolinasi tongkol tanaman yang lain, sedangkan tongkolnya sendiri terpolinasi oleh polen tanaman lain.

Ragam genetik merupakan ukuran tentang besarnya perbedaan genetik dari inbred yang terbaik sampai yang terburuk (Gunawan, 2009). Makin besar ragam genetik makin mudah dilakukan seleksi. Besarnya keragaman genetik suatu sifat dalam populasi akan mempengaruhi besarnya heritabilitas. Agar seleksi sifat interest dapat diturunkan kepada zuriat hibrida, tetua inbred harus memiliki kemampuan pewarisan sangat penting dalam suatu perakitan varietas baru (Fehr, 1987). Evaluasi keturunan biasanya dikaitkan dengan kemampuan suatu tetua dalam suatu persilangan. Kemampuan ini disebut daya gabung. Dengan melihat rerata keturunan dapat ditentukan apakah suatu tetua mempunyai daya gabung terhadap tetua lain (Allard, 
1989). Daya gabung adalah kemampuan genotipe untuk memindahkan sifat yang diinginkan kepada keturunannya. Ada dua macam daya gabung, yakni daya gabung umum dan daya gabung khusus. Daya gabung umum merupakan kemampuan suatu genotipe untuk menunjukkan kemampuannya rerata keturunanannya bila disilangkan dengan sejumlah genotipe lain yang dikombinasikan. Daya gabung khusus adalah kemampuan suatu kombinasi persilangan untuk menunjukkan penampilan keturunannya. Evaluasi daya gabung merupakan salah satu cara menilai kemampuan inbrida berdasarkan daya hasil persilangan dengan tetuanya yang digunakan sebagai genotipe penguji (Allard, 1989).

Faktor utama yang menentukan keunggulan hibrida adalah daya gabung galur murni. Pada awalnya, daya gabung merupakan konsep umum untuk mengklasifikasikan galur murni secara relatif menurut penampilan hibridanya (Hallauer dan Miranda, 1988). Daya gabung umum merupakan penampilan rata-rata galur murni dalam berbagai kombinasi hibrida, sedangkan daya gabung khusus menunjukkan penampilan galur murni dalam suatu kombinasi lainnya (Sprague dan Tatum, 1942).

Penelitian bertujuan untuk: (1) Mengevaluasi daya gabung tetua inbred kepada zuriat kuning kisut polinasi terbuka, (2 ) Mengetahui adanya ragam genetik dan heritabilitas untuk sifat interest yang dievaluasi, dan (3) Mengevalusi perbandingan biji jagung manis kuning kisut 12:4. Hipotesis yang diajukan yaitu (1) Daya gabung terdapat pada tetua inbred zuriat kuning kisut polinasi terbuka, dengan semua karakter yang diamati, (2 ) Untuk sifat interest yang dievaluasi terdapat ragam genetik dan heritabilitas pada karakter yang diamati dan (3) Mendapatkan biji jagung manis kuning kisut dengan perbandingan 12:4.

\section{BAHAN DAN METODE}

Penelitian ini dilaksanakan di Kebun Percobaan Politeknik Negeri Lampung, Desa Hajimena, Lampung Selatan pada bulan September 2009 sampai bulan Januari 2010.Bahan yang digunakan dalam penelitian ini adalah pupuk NPK majemuk. Selain bahan tanam, juga digunakan lima tetua jagung manis yang diambil data tahun 2008 untuk dibandingkan dengan jagung manis kuning kisut yang diambil pada tahun 2009.

Alat-alat yang digunakan dalam penelitian ini adalah: tugal, polybag, cutter, stapler, mistar, gunting, meteran, kertas label, tali rafia, karet gelang, jangka sorong, refaktometer, dan alat tulis.
Penelitian ini dilakukan dalam Rancangan Acak Kelompok Lengkap (RAKL) dengan tiga ulangan. Data dianalisis ragam untuk mendapatkan kuadrat nilai tengah dan kuadrat nilai tengah harapan yang akan digunakan untuk menduga ragam genetik dan heritabilitas. Ragam genetik $\left(\hat{o}^{2} \mathrm{~g}\right)$ dan heritabilitas broad-sense $\left(\mathrm{h}^{2}{ }_{\mathrm{BS}}\right)$ dihitung menggunakan model matematika berdasarkan Hallauer dan Miranda (Hikam, 2010).

\section{HASIL DAN PEMBAHASAN}

Analisis Sifat Vegetatif dan Generatif. Perbedaan sifat vegetatif dan generatif ditetapkan berdasarkan analisis ragam (tabel 1). Perbedaan antar kultivar tampak untuk karakter vegetatif dan generatif, yaitu: jumlah daun, jumlah malai, diameter tongkol $(\mathrm{P}<0,05)$. Sedangkan untuk karakter tinggi tanaman, posisi tongkol, dan panjang tongkol, jumlah baris per biji dan kadar sukrosa tidak berbeda. Walaupun jumlah daun, jumlah malai, dan diameter tongkol berbeda antarkultivar, hanya jumlah malai dan kadar sukrosa yang memenuhi standar komersial. Sedangkan untuk karakter yang lain memerlukan seleksi lebih lanjut.

Seleksi lanjutan dapat dilakukan dengan menggunakan plasma nutfah introduksi (kultivar yang berasal dari luar populasi). Nilai koefisien keragaman d" $25,6 \%$ (populasi homogen), sehingga seleksi menggunakan persilangan antarkultivar yang ada di dalam populasi tidak akan menghasilkan peningkatan yang berarti (Hallauer dan Miranda, 1981).

Ragam Genetik ó ${ }^{2} \mathbf{g}$ dan Heritabilitas Broad-sense $\mathbf{h}^{2}{ }_{\text {Bs. }}$ Tabel 2 menunjukkan nilai ragam genetik, heritabilitas, dan koefisien keragaman genetik untuk seluruh variabel yang diamati. Nilai ragam genetik dan heritabilitas berbeda dari nol (> 1 GB) untuk jumlah daun, jumlah malai, dan diameter tongkol. Nilai ragam genetik sangat mempengaruhi keberhasilan suatu seleksi dalam pemuliaan tanaman. Semakin besar nilai ragam genetik yang terdapat di dalam suatu populasi tanaman semakin mudah bagi pemulia untuk memilih genotipe-genotipe terbaik yang diinginkan (Hikam, 2010).

Jika nilai ragam genetik yang didapat tidak berbeda dari nol $(<1 \mathrm{~GB})$, tampilan fenotipenya seragam sehingga sulit untuk menentukan genotipegenotipe yang terbaik. Hal ini muncul pada karakter tinggi tanaman, posisi tongkol, jumlah baris biji, panjang tongkol, dan kadar sukrosa.

Hasil ragam genetik yang didapat berbeda antarvariabel. Perbedaan besarnya ragam genetik antarvariabel tidak digunakan untuk menyatakan besar 
Tabel 1. Analisis kuadrat nilai tengah untuk peubah vegetatif dan generatif

\begin{tabular}{lccccc}
\hline Sumber keragaman & $\begin{array}{c}\text { Derajat } \\
\text { bebas }\end{array}$ & $\begin{array}{c}\text { Tinggi } \\
\text { tanaman }\end{array}$ & $\begin{array}{c}\text { Posisi } \\
\text { tongkol }\end{array}$ & Jumlah daun & Jumlah malai \\
\hline Kelompok & 2 & 104,51 & 148,21 & 1,84 & 0,78 \\
Kultivar & 4 & 281,45 & 75,83 & $6,39 * *$ & $49,24^{*}$ \\
Galat & 8 & 189,83 & 128,38 & 0,94 & 12,46 \\
Total & 14 & & & & \\
\hline $\bar{X}$ & & 133,85 & 57,5 & 12,90 & 8,90 \\
KK(\%) & & 10,29 & 19,71 & 7,52 & 8,68 \\
Standar komersial & & $\geq 150 \mathrm{~cm}$ & $48-52 \%$ & $15-17$ & $\geq 17$ \\
\hline Sumber keragaman & Derajat & Diameter & Panjang & Jumlah baris biji & Kadar sukrosa \\
& bebas & tongkol & tongkol & per tongkol & \\
\hline Kelompok & 2 & 0,330 & 1,94 & 1,94 & 8,07 \\
Kultivar & 4 & $0,760 *$ & 9,30 & 0,81 & 16,40 \\
Galat & 8 & 0,140 & 6,55 & 2,07 & 8,15 \\
Total & 14 & & & & 27,31 \\
\hline $\bar{X}$ & & 4,085 & 19,89 & 11,74 & 10,45 \\
KK(\%) & 9,160 & 12,89 & 12,25 & $\geq 16 \%$ \\
Standar komersial & & $4,500 \mathrm{~cm}$ & $16 \mathrm{~cm}$ & $14-16$ & \\
\hline
\end{tabular}

$\mathrm{KK}=$ koefesien keragaman, $*$ = berbeda pada $\mathrm{P}<0,05$.

Tabel 2. Nilai ragam genetik (ó $\left.{ }^{2} \mathrm{~g}\right)$, heritabilitas broad-sense $\left(\mathrm{h}^{2}{ }_{\mathrm{BS}}\right)$, dan koefisien dan keragaman genetik (KKg \%) seluruh variabel yang diamati

\begin{tabular}{lccc}
\hline Variabel Pengamatan & $\sigma^{2} \mathrm{~g} \pm \mathrm{GB}$ & $\mathrm{h}^{2}{ }_{\mathrm{BS}} \pm \mathrm{GB}$ & $\mathrm{KKg}(\%)$ \\
\hline Tinggi Tanaman & $45,81 \pm 91,66$ & $16,27 \pm 32,56$ & 5,06 \\
Posisi Tongkol & $-26,28 \pm 36,10$ & $-34,64 \pm 47,60$ & 0,00 \\
Jumlah Daun & $2,71 \pm 1,84^{*}$ & $42,61 \pm 28,93^{*}$ & 12,76 \\
Jumlah Malai & $18,39 \pm 14,48^{*}$ & $37,34 \pm 29,40^{*}$ & 22,69 \\
Diameter Tongkol & $0,31 \pm 0,22^{*}$ & $40,79 \pm 28,81^{*}$ & 13,63 \\
Jumlah Baris & $-0,63 \pm 0,51$ & $-0,78 \pm 62,96$ & 0,00 \\
Panjang Tongkol & $1,37 \pm 3,05$ & $14,78 \pm 32,79$ & 5,89 \\
Kadar Sukrosa & $4,12 \pm 5,07$ & $25,15 \pm 30,91$ & 7,44 \\
\hline
\end{tabular}

KKg : koefesien keragaman genetik, * ó $^{2} \mathrm{~g}$ dan $\mathrm{h}_{\mathrm{BS}}^{2}>1 \mathrm{~GB} ;$ ó $^{2} \mathrm{~g}$ dan $\mathrm{h}_{\mathrm{BS}}^{2}$ berbeda dari nol.

kecilnya ragam genetik. Keberartian ragam genetik ditentukan oleh mampu atau tidaknya memenuhi 1 kali galat baku. Angka negatif pada ragam genetik disebabkan nilai kuadrat tengah genotipe lebih kecil daripada kuadrat tengah interaksi (genotipe $\mathrm{x}$ lingkungan). Artinya pengaruh lingkungan lebih besar daripada pengaruh genetik sehingga tidak dapat diabaikan.

Nilai heritabilitas yang lebih besar dari nol menunjukkan karakter-karakter tetua tersebut lebih mudah diwariskan kepada keturunannya. Hal itu memberi peluang besar untuk memperbaiki sifat genetik pada kultivar-kultivar tersebut melalui program seleksi. Nilai heritabilitas suatu karakter perlu diketahui untuk menduga kemajuan dari suatu selesksi. Selain itu juga dapat mengetahui apakah karakter yang diwariskan dipengaruhi oleh faktor genetik atau lingkungan.

Nilai koefesien keragaman genetik $(\mathrm{KKg})$ menunjukkan tingkat kepercayaan terhadap ó$^{2} \mathrm{~g}$. 
Semakin kecil nilai KKg semakin homogen data yang diperoleh dan semakin baik analisis ó ${ }^{2} \mathrm{~g}$ yang di lakukan. Nilai $\mathrm{KKg}>25,6 \%$ menunjukkan bahwa karakter tersebut harus diseleksi ulang. Hal itu karena data untuk karekter tersebut tidak homogen. Koefisien keragaman genetik $<25,6 \%$ menunjukkan bahwa pengaruh genetik lebih besar daripada pengaruh lingkungan dan seluruh tampilan fenotipe merupakan hasil kerja genetik. Dengan demikian pengaruh lingkungan dapat diabaikan.

\section{Daya Gabung}

Namun sebaliknya pada KKg > 25,6\% menunjukkan bahwa lingkungan berpengaruh terhadap kinerja genetik sehingga tidak dapat diabaikan (Hikam, 2003). Berdasarkan data tersebut nilai KKg yang baik adalah 5,06\%. Hal tersebut karena semakin kecil nilai KKg maka semakin baik pengaruh genetiknya. Nilai $\mathrm{KKg}$ yang kecil dapat menghilangkan perbedaan karena tanaman menjadi seragam.

Daya gabung umum merupakan penampilan ratarata galur murni dalam berbagai kombinasi hibrida (Chaudhary, 1982). Ada dua macam daya gabung, yakni daya gabung umum dan daya gabung khusus. Daya gabung umum merupakan kemampuan tetua inbred untuk mewariskan sifat interest kepada zuriat hibrida secara aditif. Dalam hal ini daya gabung umum ekspresi pada zuriat adalah rerata kinerja tetua. Daya gabung khusus merupakan kemampuan tetua inbred untuk mewariskan sifat interest kepada zuriat hibrid yang besarnya menyimpang secara nyata terhadap DGU (aditif). Dengan demikian DGK merupakan ekspresi dominan (Hikam, 2010).

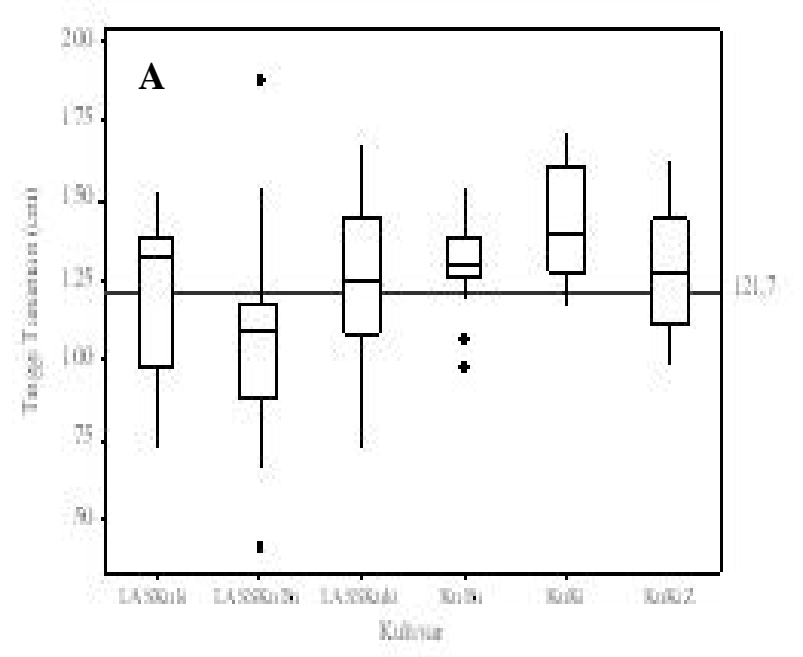

Daya gabung dalam penelitian ini dianalisis boxplot (Gambar 1a-h). Dari analisis boxplot tersebut diperoleh bahwa tinggi tanaman, posisi tongkol, jumlah daun, jumlah malai, panjang tongkol, dan jumlah baris biji menunjukkan daya gabung umum, yaitu tidak menyimpang dari garis rerata $\overline{\mathrm{X}}$ Untuk karakter diameter tongkol dan kadar sukrosa menunjukkan daya gabung khusus, yaitu menyimpang dari garis rerata Bila tetua bertepatan dengan standar komersial maka karakter tersebut tidak perlu DGK. Bila tetua lebih kecil dari tetua maka karakter tersebut perlu DGK.

\section{Segregasi Bentuk Biji}

Tabel 3 menunjukkan hasil segregasi pada kultivar kuning kisut. Pengamatan dilakukan pada 15 tongkol jagung manis kuning kisut. Dari 15 tongkol jagung manis yang diamati tidak semuanya merupakan jagung manis dengan fenotipe biji kuning kisut. Rasa manis pada jagung manis ditentukan oleh bentuk tampilan kisut pada biji jagung manis. Berdasarkan jumlah biji kisut, dapat dilihat bahwa hampir semua sampel yang diamati membawa sifat manis, hal tersebut dapat dilihat dengan adanya biji kisut pada tiap sampel. Hal tersebut juga didukung dengan penelitian Nurmayanti (2011).

Pada penelitian ini zuriat ditanam dalam bentuk biji kisut. Dengan demikian bila tanaman diself akan terjadi segregasi biji dalam bentuk sebagai berikut:

$1.100 \%$ kuning bulat atau $100 \%$ kuning kisut

2.9 kuning bulat : 7 kuning kisut

3.12 kuning bulat : 4 kuning kisut

4. 15 kuning bulat : 1 kuning kisut

5. 9 kuning bulat : 3 kuning kisut : 3 putih bulat : 1 putih kisut

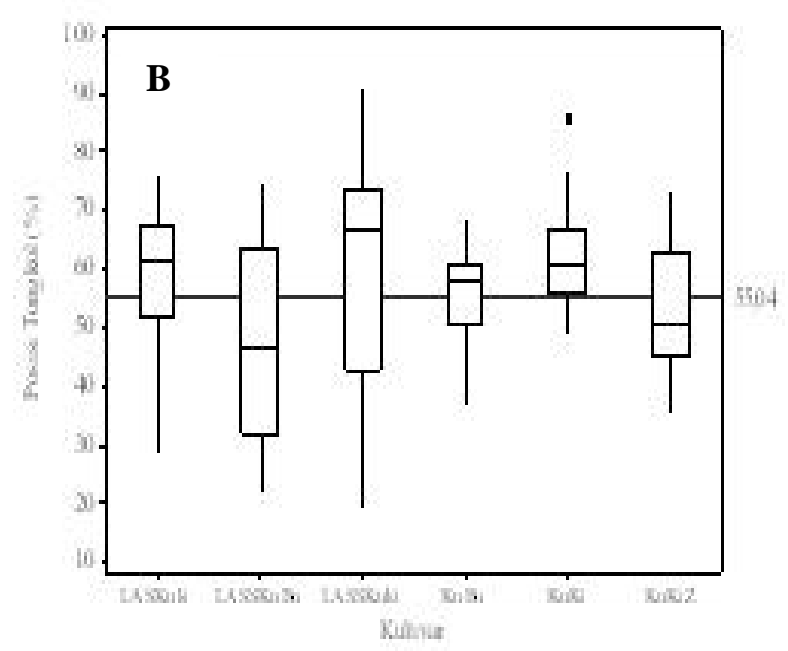

Gambar 1. Analisis boxplot daya gabung. A= tinggi tanaman, $\mathrm{B}=$ posisi tongkol. 

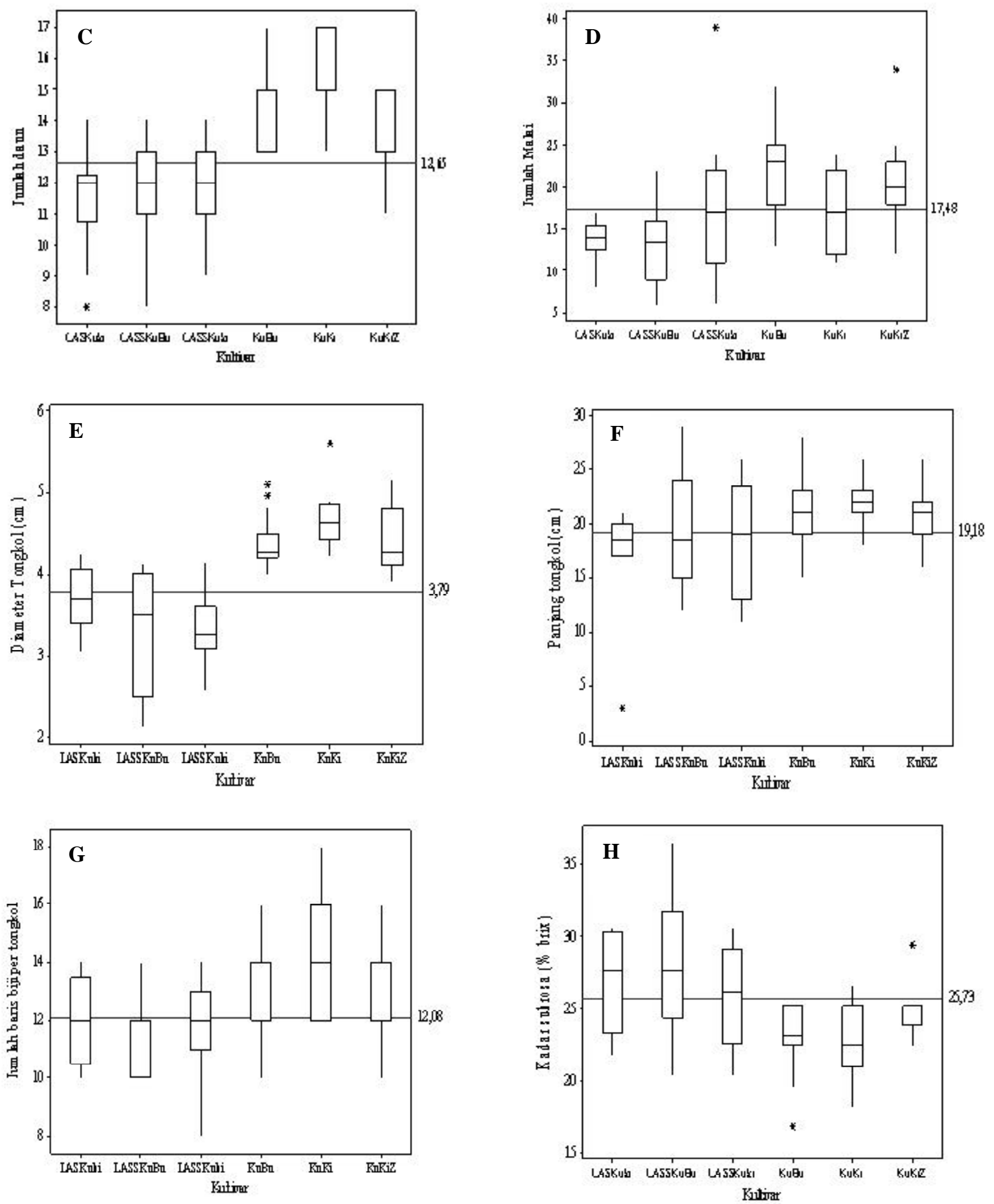

Gambar 1 (lanjutan). Analisis boxplot daya gabung. $\mathrm{C}=$ jumlah baris, $\mathrm{D}=$ jumlah malai, $\mathrm{E}=$ diameter tongkol, $\mathrm{F}$ = panjang tongkol, $\mathrm{G}=$ jumlah baris, dan $\mathrm{H}=$ kadar sukrosa. 
Tabel 5. Fenotipe kuning kisut hasil amatan pada sampel

\begin{tabular}{|c|c|c|c|c|c|c|c|c|}
\hline \multirow{2}{*}{ Ulangan } & \multirow{2}{*}{ Sampel } & \multicolumn{5}{|c|}{ Amatan } & \multirow{2}{*}{$\begin{array}{c}\text { Fenotipe } \\
\text { kuning kisut }\end{array}$} & \multirow{2}{*}{$\begin{array}{c}\% \text { biji kuning } \\
\text { kisut }\end{array}$} \\
\hline & & Total & $\mathrm{KuBu}$ & Kuki & $\mathrm{puBu}$ & Puki & & \\
\hline 1 & 1 & 195 & 0 & 195 & 0 & 0 & $\mathrm{Ya}$ & 100,00 \\
\hline 1 & 2 & 212 & 0 & 212 & 0 & 0 & Ya & 100,00 \\
\hline 1 & 3 & 232 & 4 & 228 & 0 & 0 & Ya & 98,28 \\
\hline 1 & 4 & 207 & 0 & 207 & 0 & 0 & Ya & 100,00 \\
\hline 1 & 5 & 256 & 0 & 256 & 0 & 0 & $\mathrm{Ya}$ & 100,00 \\
\hline 2 & 1 & 246 & 146 & 47 & 42 & 11 & $\mathrm{Ya}$ & 19,11 \\
\hline 2 & 2 & 226 & 192 & 23 & 4 & 7 & $\mathrm{Ya}$ & 10,18 \\
\hline 2 & 3 & 217 & 168 & 49 & 0 & 0 & $\mathrm{Ya}$ & 22,58 \\
\hline 2 & 4 & 309 & 186 & 31 & 53 & 39 & $\mathrm{Ya}$ & 10,03 \\
\hline 2 & 5 & 305 & 249 & 56 & 0 & 0 & $\mathrm{Ya}$ & 18,36 \\
\hline 3 & 1 & 336 & 336 & 0 & 0 & 0 & Tidak & 0,00 \\
\hline 3 & 2 & 314 & 207 & 58 & 41 & 8 & $\mathrm{Ya}$ & 18,47 \\
\hline 3 & 3 & 338 & 262 & 76 & 0 & 0 & $\mathrm{Ya}$ & 22,49 \\
\hline 3 & 4 & 388 & 306 & 0 & 82 & 0 & $\mathrm{Ya}$ & 0,00 \\
\hline 3 & 5 & 161 & 132 & 0 & 29 & 0 & $\mathrm{Ya}$ & 0,00 \\
\hline
\end{tabular}

Menurut (Hikam, 2003) jika dalam satu tongkol jagung manis terdapat perbandingan 9 biji bulat : 7 biji kisut $(43,75 \%)$ atau 12 biji bulat : 4 biji kisut (25\%) maka jagung tersebut sudah dapat dikatakan jagung manis. Pada Tabel 5 dapat dilihat bahwa bahwa beberapa tongkol mengandung biji putih pada tongkolnya yaitu pada ulangan dua sampel satu, dua, empat dan pada ulangan tiga sampel dua, empat, lima. Sedangkan pada ulangan satu semua sampel yang diamati mengandung biji kisut sampai $100 \%$. Hal yang dapat mempengaruhi segregasi tersebut adalah faktor dari dalam gen itu sendiri. Keadaan lingkungan juga sangat mempengaruhi penampakan gen. Dalam kenyataannya penampakan fenotipe adalah akibat interaksi antara genotipe dan lingkungan (Welsh, 1981).

\section{KESIMPULAN}

Dari penelitian ini dapat disimpulkan bahwa untuk karakter tinggi tanaman, posisi tongkol, jumlah daun, jumlah malai, panjang tongkol, dan jumlah baris biji yang terlihat adalah daya gabung umum. Sedangkan untuk karakter diameter tongkol, dan kadar sukrosa adalah daya gabung khusus.Nilai ragam genetik $\left(\mathrm{o}^{2} \mathrm{~g}\right)$ dan heritabilitas broad-sense $\left(\mathrm{h}^{2}{ }_{\mathrm{BS}}\right)$ berbeda dari nol untuk jumlah daun, jumlah malai, dan diameter tongkol. Dari 15 tongkol jagung manis kuning kisut yang diamati. Rasa manis pada jagung manis ditentukan oleh bentuk tampilan kisut pada biji jagung manis. Berdasarkan jumlah biji kisut, dapat dilihat bahwa hampir semua sampel yang diamati membawa sifat manis dengan perbandingan 12:4.

\section{DAFTAR PUSTAKA}

Allard, R. W. 1989. Principles of Plant Breeding. John Wiley and sons. New York. NY.

Chaudhary, R.C. 1982. Introduction to Plant Breeding. Oxford and IBH., New Delhi. 267 pp.

Creech, R.G. 1965. Genetic Control of Carbohydrate Syntesis in Maize Endosperm. Genetics 52: 1175-1186.

Fehr, W.R. 1987. Principles of Cultivar Development. Vol.1. Theory and Technique. Macmillan Publ. Co. New York. NY. 536 hlm.

Gunawan, A. 2009. Budidaya Tanaman Jagung Lokal (Zea mays L.).

Hallauer, A.R., and J.B. Miranda Fo. 1988. Quantitative Genetics in Maize Breeding. Iowa State University Press. Iowa. USA

Hikam, S. 2003. Pemanfaatan Epistasis Bentuk Biji Didalam Perakitan Jagung Manis Harapan Lampung Super Sweet. Poster pada Simposium 
Nasional dan Kongres Peragi VIII. Bandar Lampung. 8-10 Juli 2003.

Hikam, S. 2003. Program Pengembangan Jagung Manis Lampung Super Sweet (LASS) Dan Lampung Golden Bantam (LAGB). Fakultas Pertanian Universitas Lampung. Bandar Lampung. Naskah lepas $17 \mathrm{hlm}$.

Hikam, S. 2004. Biometrika: Penggunaan Biometrika dalam Desain Penelitian, Analisis Data, dan Penyimpulan. Fakultas Pertanian Universitas Lampung. Bandar Lampung. Naskah lepas 19 hlm.

Hikam, S. 2008. Pemuliaan Tanaman Lanjutan. Fakultas Pertanian Universitas Lampung. Bandar Lampung. Dalam penerbitan $36 \mathrm{hlm}$.
Hikam, S. 2009. Pemanfaatan Segregasi Epistatik dan Peningkatan Efisiensi Kalmodulin pada Biji dalam Perakitan Jagung Manis Hibrid. http://epistatikunila.blogspot.com/2009/06/ pemanfaatan-segregasi-epistatikdan.html. Diakses tanggal 18 Februari 2010.

Hikam, S., P.B. Timotiwu, dan D. Sudrajat. 2009. Perakitan Benih Jagung Manis Fenotipe Biji Bulat melalui Modifikasi Segregasi Epistatik Dialel 9:7. Dalam 100 inovasi Indonesia. Ristek. http://www.bic.web.id/in/ketahanan-pangan/132keturunan-yang-manis-dan-nirmanis.html.

Hikam, S. 2010. Teknik Perancangan dan Analisis Pemuliaan Tanaman. Fakultas Pertanian Universitas Lampung. Bandar Lampung. Dalam penerbitan $31 \mathrm{hlm}$.

Iskandar. 2003. Dasar-dasar Pemuliaan Tanaman. Penerbit Kanisius. Yogyakarta. $182 \mathrm{hlm}$. 